\title{
IS PENICULUS FISTULA FISTULA NORDMANN, 1832 REPORTED ON CORYPHAENA HIPPURUS LINNAEUS, 1758 FROM TURKEY? UPDATED DATA WITH FURTHER COMMENTS AND CONSIDERATIONS
}

Ahmet ÖKTENER *and Murat ŞIRIN **

* Sheep Research Institute, Department of Fisheries, Çanakkele Street 7 km, Bandırma, Balıkesir, Turkey, TR-10200, ahmetoktener@yahoo.com,mothocya@hotmail.com

KEYWORDS: Peniculus fistula, Mullus, Coryphaena, Marmara Sea, checklist, host. ABSTRACT

53 striped surmullet, Mullus surmuletus Linnaeus, 1758 (Teleostei, Mullidae), were collected from the Marmara Sea, Turkey and examined for metazoan parasites in July 2017. The parasitic copepod, Peniculus fistula fistula Nordmann, 1832 (Pennellidae), was collected from all the hosts, both on fins and body surface. This is the second report of this copepod in Turkish marine waters. Although Peniculus fistula fistula was reported for the first time on Coryphaena hippurus Linnaeus, 1758 by Öktener (2008), there was an indefiniteness and doubt about the occurrence of this parasite. This study aimed to confirm occurrence of Peniculus fistula fistula in Turkey and to present revised host list with comments.

ZUSAMMENFASSUNG: Ist der an Coryphaena hippurus festgestellte Linnaeus, 1758 Ruderfußkrebs Peniculum fistula fistula Nordmann, 1832 aus der Türkei? Aktualisierte Angaben mit weiteren Kommentaren und Betrachtungen.

53 Steifenbarben Mullus surmuletus Linnaeus, 1758 (Teleostei, Mullidae) wurden aus dem Marmara Meer, Türkei gesammelt und im Juli 2017 auf Vorkommen metazoischer Parasiten untersucht. Der parasitäre Ruderfußkrebs Peniculus fistula fistula Nordmann, 1832 (Pennellidae, Copepoda) wurde von allen Wirtstieren, sowohl von den Kiemen, als auch von der Körperoberfläche gesammelt. Vorliegender Bericht ist der zweite betreffend das Vorkommen dieser Copepoden Art in marinen Gewässern der Türkei. Obwohl Peniculus fistula fistula zum erstenmal von Öktener (2008) an Coryphaena hippurus Linnaeus, 1758 gemeldet wurde, gab es eine Unbestimmtheit und Zweifel betreffend das Vorkommen dieses Parasiten. Vorliegende Untersuchung ist darauf ausgerichtet, das Vorkommen von Peniculus fistula fistula in der Türkei zu bestätigen und eine revidierte Liste der Wirte mit Kommentaren vorzulegen.

REZUMAT: Copepodul Peniculum fistula fistula Nordmann, 1832 semnalat pe Coryphaena hippurus Linnaeus, 1758 este din Turcia? Date actualizate cu comentarii și considerații.

53 de pești din specia Mullus surmuletus Linnaeus, 1758 (Teleostei, Mullidae) au fost colectați în luna iulie 2017 din Marea Marmara, Turcia și examinați în vederea identificării de paraziți metazoici. Copepodul parazitar Peniculus fistula fistula Nordmann, 1832 (Pennellidae, Copepoda) a fost colectat pe toate speciile gazdă atât de pe înotătoare, cât și de pe suprafața corpului. Prezentul raport este al doilea referitor la prezența acestui copepod în apele marine ale Turciei. Cu toate că Peniculus fistula fistula a fost semnalat pentru prima dată de Öktener (2008) pe Coryphaena hippurus Linnaeus, 1758 a existat o nedumerire și dubii asupra prezenței acestui parazit. Prezentul studiu are obiectivul de a confirma existența speciei Peniculus fistula fistula în Turcia și a prezenta o listă revizuită și comentată a gazdelor. 


\section{INTRODUCTION}

In Turkey, the total length of the sea coast is $8,333 \mathrm{~km}$, including the Black Sea, the Mediterranean Sea, the Aegean Sea and the Marmara Sea (Kılıç, 1999). The Marmara Sea being an unique inland sea displays the transitional environment between the Black Sea and the Mediterranean Sea (Bănăduc et al., 2016). Bilecenoğlu et al. (2014) indicated the fish species diversity according to Turkish seas as follows: the Aegean Sea 449 sp.; Turkish Mediterranean Sea coasts 441 sp.; Marmara Sea 257 sp.; Turkish Black Sea coasts 154 sp. There are limited studies on the parasitic copepods of fish in the Marmara Sea.

The striped surmullet, Mullus surmuletus Linnaeus, 1758 (Perciformes, Mullidae) is a fish species of important commercial value, distributed in Eastern Atlantic, the Mediterranean Sea and the Black Sea. It is a carnivorous fish that feeds mainly on benthic organisms such as shrimps and amphipods, polychaetes, molluscs, and benthic fishes. It is a demersal and oceanodromous fish. (Froese and Pauly, 2017)

Members of Pennellidae (Copepoda, Siphonostomatoida) are parasitic copepods of marine fish and cetaceans. The genus Peniculus Nordmann, 1832 (Pennellidae) includes 11 nominal species. The species of the genus penetrate often the fins of their hosts (Boxshall, 1986; Vidjak et al., 2008; Venmathi Maran et al., 2012; Moon and Hoi, 2014).

Five species of parasitic copepods (Caligus centrodonti Baird, 1850; Colobomatus mulli Essafi et al., 1983; Colobomatus steenstrupi Richiardi, 1876; Hatschekia mulli van Beneden, 1851; Peniculus fistula fistula Nordmann, 1832) from the surmullet have been listed by Raibaut et al. (1998).

Peniculus fistula fistula Nordmann, 1832 was reported on Coryphaena hippurus Linnaeus, 1758 from Aegean Sea, Turkey by Öktener (2008), there was an indefiniteness and doubt about the occurrence of this parasite. This study aims to confirm occurrence of Peniculus fistula fistula in Turkey and to present the revised list of host species parasitizing Peniculus fistula fistula.

\section{MATERIAL AND METHODS}

53 surmullets were sampled by trawling from Marmara Sea, Turkey $\left(40^{\circ} 28^{\prime} \mathrm{N}, 27^{\circ} 15^{\prime} \mathrm{E}\right.$ $-40^{\circ} 28^{\prime} \mathrm{N}, 27^{\circ} 13^{\prime} \mathrm{E}$ ) in 2017. Parasite recovered from the hosts were fixed in $70 \%$ ethanol. Some specimens were cleared in lactic acid and their appendages were dissected out by using Wild M5 stereo microscope. Dissected parts were mounted on slides in glycerin-gelatine mounting medium. The photos were taken with the aid of Canon camera (EOS 1100D) connected to a microscope. All measurements are in millimeters. Terminology of appendage structure follows (Boxshall, 1986; Vidjak et al., 2008; Venmathi Maran et al., 2012; Moon and Hoi, 2014). The scientific names, synonyms of host were checked through the World Register of Marine Species and related online databases (Walter and Boxshall, 2018). The information of feeding habits, habitat characteristics of host were prepared according to Froese and Pauly (2018). The voucher specimen (ESFM- COP/2017-5: Peniculus fistula fistula) were deposited in the collections of the Museum of Ege University (ESFM), Faculty of Fisheries, Turkey.

\section{RESULTS AND DISCUSSION}

Siphonostomatoida Thorell, 1859; Pennellidae Burmeister, 1835; Peniculus Nordmann, 1832; Peniculus fistula fistula Nordmann, 1832 (Figs. 1-3).

Infestation values: $82.75 \%$ striped surmulet were infested with Peniculus fistula fistula, with a mean intensity of 1.4 and abundance of 1.7 .

Infestation of site: parasites were attached to host with their antenna embedded in all of the fins ray and body surface (Figs. 3a-f). 


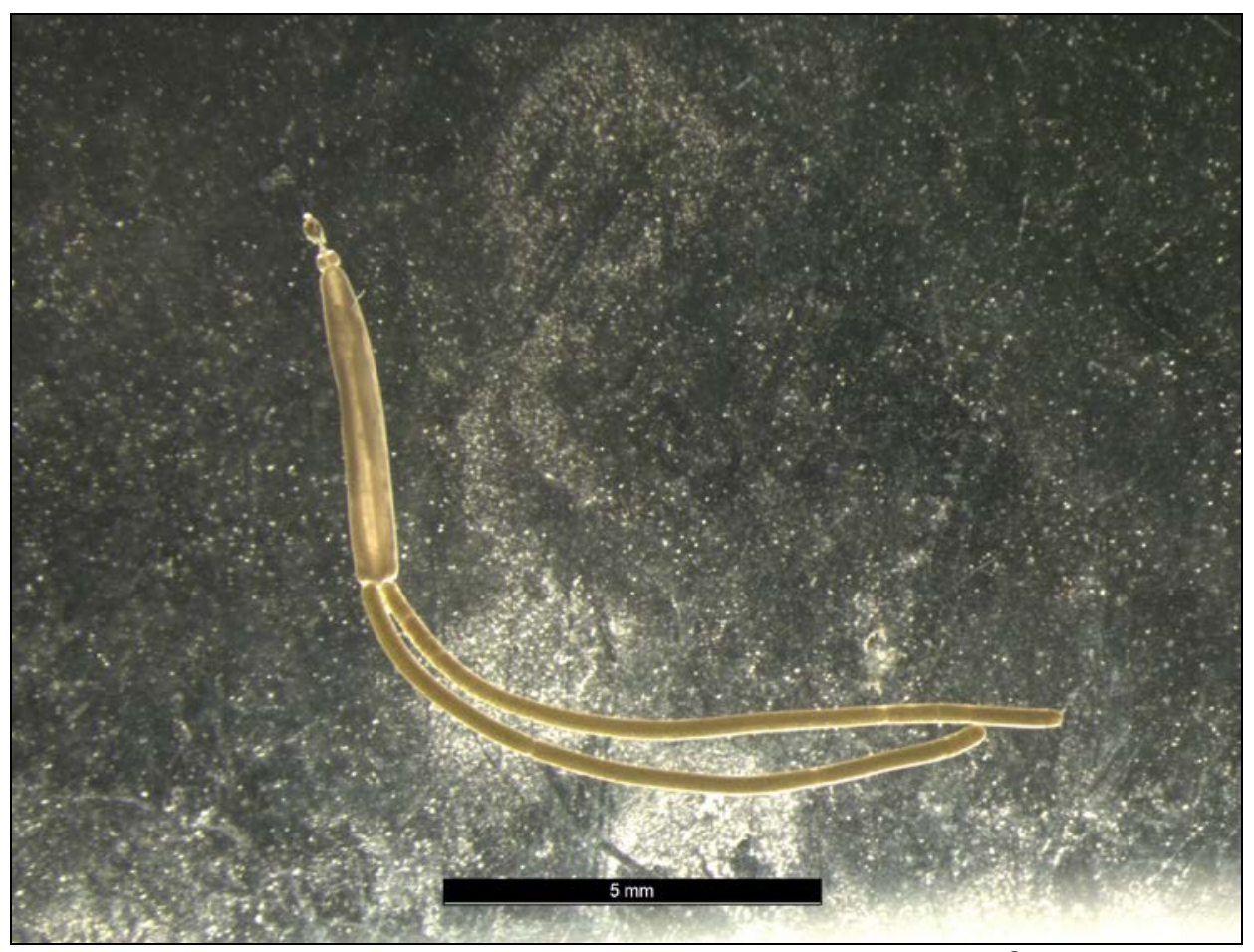

Figure 1: Peniculus fistula fistula Nordmann, 1832 +

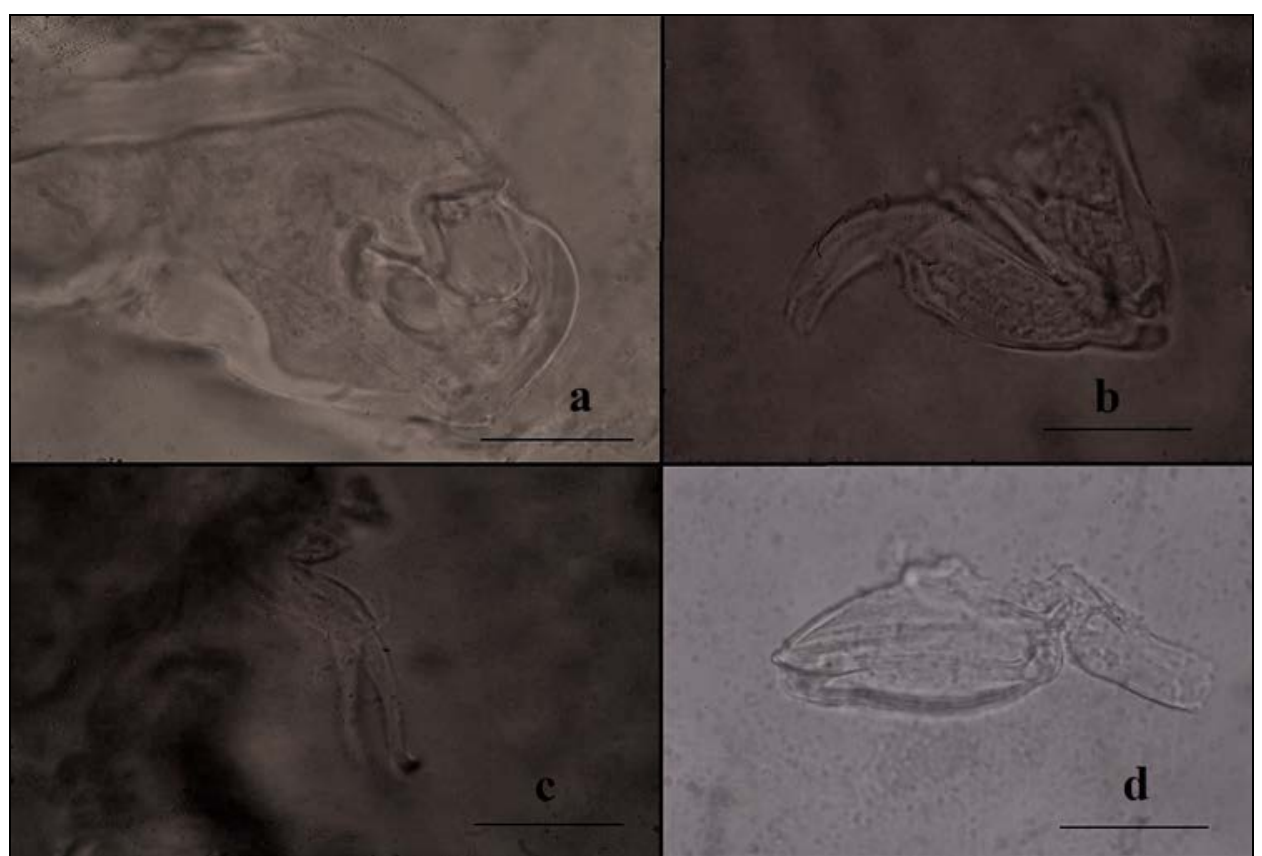

Figure 2: Peniculus fistula fistula a) antenna $(0.02 \mathrm{~mm})$,

b) maxilla (0.02 mm), c) maxillule (0.03 mm), d) leg one (0.045 mm). 


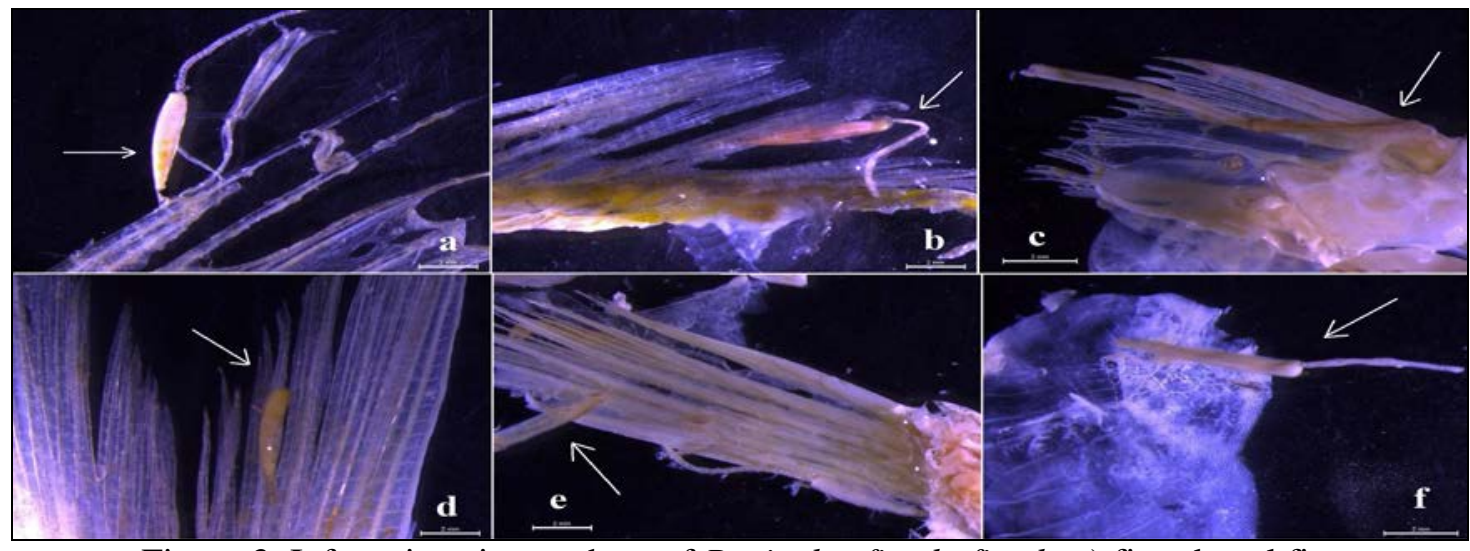

Figure 3: Infestation sites on host of Peniculus fistula fistula a) first dorsal fin,

b) second dorsal fin, c) anal fin, d) caudal fin, e) pectoral fin, f) scale (two mm).

Morphological characters of postmetamorphosis female. Body (Fig. 1) 5.47 (4.28$6.49 ; \mathrm{n}=19) \mathrm{mm}$ long, comprising oval head, slender neck, large trunk and reduced abdomen. Cephalothorax $0.354(0.28-0.69 ; n=19) \mathrm{mm}$ longer than wide $0.24(0.21-0.26 ; n=19)$, ovoidal, flattened dorsally but convex ventrally, with pair of rounded swellings posteriorly to leg one (Fig. 3c). Neck $0.23(0.17-0.3 ; n=19) \mathrm{mm}$ long, slender, shorter than cephalothorax, consisting of three somites bearing legs one, two, and three. Trunk cyclindrical, 6.7 times longer $4.65(3.46-5.64 ; \mathrm{n}=19)$ than wide $0.69(0.52 \times 0.79 \mathrm{~mm})$, bearing leg four proximally. Abdomen elongate, slightly rounded. Fourth pedigerous somite trapezoidal, incorporated into anterior end of trunk. Egg sacs 7.83 (4.56-11) mm long, linear, longer than body. Caudal rami located on abdominal process, with two long, three subequal medium-sized, and one small setae. Antennules, maxilliped, leg five absent. Antenna (Fig. 2a) two-segmented, chelate; terminal segment claw-like, with small seta at base. Maxillule (Fig. 2c) with two lobes having one short and two long setae. Maxilla (Fig. 2b) two-segmented; proximal segment broad; distal claw blunt and curved, with transverse striations and fine spinules. Legs one (Fig. 2d) and two located close together, gap between legs two-three, and legs three-four almost equal. Legs onetwo with one setule on anterior margin.

Examination of the parasite specimens showed that they were Peniculus fistula fistula Nordmann, 1832 (Pennellidae) according to the general drawings and descriptions given by Boxshall (1986), Vidjak et al. (2008), Venmathi Maran et al. (2012), Moon and Choi (2014).

Peniculus fistula fistula was collected for the first time on the ventral fin of the common dolphinfish, Coryphaena hippurus from the Aegean Sea, Turkey (Öktener, 2008). But Bunkley-Williams and Williams (2009), Williams and Bunkley-Williams (2009, 2010) have made interpretations about Öktener’s (2008) article.

Bunkley-Williams and Williams (2009) disapproved that Öktener (2008) examined few fish as quantitative for determination parasite fauna of the common dolphinfish. As is known, it is quite expensive to provide the common dolphinfish in large quantities. It is difficult to provide the project or scholarsip about determination of fish parasite fauna. Öktener's (2008) study was carried out with author's limited possibilities. Thus, author obtained small collection of hosts. Öktener (2008)' short paper did not describe a new species. Although, Bunkley-Williams and Williams (2009) criticized Öktener (2008) for examination of limited fish for determination parasite fauna of the common dolphinfish, Bunkley-Williams et al. (1998). Bunkley-Williams and Williams (2000) reported parasite records about limited fish samples. For example, Bunkley-Williams and Williams (2000) found Glossobius 
impressus (Cymothoidae) on just one specimen of Hirundichthys affinis from Caribbean. Bunkley-Williams et al. (1998) also determined one parasite on five samples examined of Micropogonias furnieri; one parasite on five samples examined of Hemiramphus brasiliensis; one parasite on six samples examined of Scomberomorus brasiliensis. Thus in these cases, should be more appropriate to use the term "accidential infestation" for Peniculus fistula fistula as reported in Öktener (2008).

Despite the fact that Bunkley-Williams and Williams (2009), Williams and BunkleyWilliams $(2009,2010)$ think that Öktener's (2008) article is a checklist because of including a list, we would like to stress that Öktener (2008)' article is a short communication which consist of four pages, not a checklist. Author's aim was not to present all of hosts of Peniculus fistula fistula or he doesn't use words as “checklist” or “all of parasites” in this publication. Öktener's publications are generally reports about ecto parasites including copepod, isopod, monogenean (Öktener, 2000, 2008; Kritsky and Öktener, 2015; Öktener et al., 2015). Öktener also published two checklists of marine and freshwater fish from Turkey in 2003 and 2005, excluding reports.

Bunkley-Williams and Williams (2009), Williams and Bunkley-Williams (2009, 2010) claimed and critisizms that any other parasite groups was included in the work of Öktener (2008). Generally, checklist studies may include several parasite groups such as protozoa, myxozoa, helminths, etc. Öktener (2008) presented some samples belonging to helminth and crustacean groups of Corypheana hippurus in the World.

However, he did not give other parasite groups because of his aim is not to produce a checklist. In addition, it was impossible to prepare a checklist of the common dolphinfish on 2008 due to very limited literature. Although, Öktener (2008) presented Peniculus fistula fistula as short report with a short parasite-host list according to referee's recommendation, Bunkley-Williams and Williams (2009), Williams and Bunkley-Williams (2009, 2010) created a parasite checklist of dolphinfish behalf to Öktener. Bunkley-Williams and Williams (2009), Williams and Bunkley-Williams (2009, 2010) also compared this created checklist with Palko et al. (1982), Dyer et al. (1997), Öktener (2008), Luna (2009) and Williams and BunkleyWilliams (2010). These checklist studies (database, checklist) were performed by professors and experienced scientists in universities.

Bunkley-Williams and Williams (2009), Williams and Bunkley-Williams (2009, 2010) claimed that Öktener (2008) gave few synonyms, erraneous and missing information about host of this parasite. Science does not move in a straight line, but in a zig-zag one. All of scientists know that synonyms and valid names of fish and parasites may change during the years. For example, Meinertia (Ceratothoa) potassoniensis and Ceratothoa poutassouiensis being typical parasite of Micromesistius poutassou which is actually Elthusa poutassouiensis (Öktener et al., 2018). Moreover, Peniculus pissipes Wilson, 1917 was accepted as a synonym of Peniculus fistula fistula according to Kabata and Wilkes (1977), Alexander (1983), and Boxshall (1986).

Bunkley-Williams and Williams (2009), Williams and Bunkley-Williams (2009, 2010) claimed that Öktener (2008) have not given some references. However, it should be considered that the publication date of Vidjak et al. (2008) occurred in the same year of the paper of Öktener (2008) so was no access to that publication. In addition, Öktener (2008) could not give some references (Wilson, 1917, 1935) because of two articles not available for author. 
Table 1: Hosts of Peniculus fistula fistula in alphabetical order; * Hosts after those listed by Bunkley-Williams and Williams (2009); ** Hosts for those not listed by BunkleyWilliams and Williams (2009).

\begin{tabular}{|l|l|}
\hline \multicolumn{1}{|c|}{ Hosts } & \multicolumn{1}{|c|}{ Authors } \\
\hline Atherina boyeri & Brian (1906) \\
\hline Atherinops affinis & Hobson (1971) \\
\hline$* *$ Anisotremus davidsonii & Hobson (1971) \\
\hline *Anisotremus scapularis & Castro-Romero et al. (2016) \\
\hline Belone belone & Vidjak et al. (2008) \\
\hline Boops boops & Zuniga and Suau (1967), Olmo (2008) \\
\hline$* *$ Brachyistius frenatus & Hobson (1971) \\
\hline Capros aper & Delamare Deboutteville and Nunes Ruivo (1951) \\
\hline${ }^{*}$ Cheilotrema fasciatum & Castro-Romero et al. (2016) \\
\hline **Cheilotrema saturnum & Hobson (1971) \\
\hline$*$ Chromis crusma & Castro-Romero et al. (2016) \\
\hline *Chromis notata & Moon and Choi (2014) \\
\hline Coryphaena hippurus & Öktener (2008) \\
\hline Cymatogaster aggregata & Love and Moser (1983) (personal communication Hanan D. A.) \\
\hline Diplodus annularis & Brian (1917) \\
\hline Diplodus vulgaris & Brian (1906) \\
\hline **Embiotoca jacksoni & $\begin{array}{l}\text { Love and Moser (1983) (communication with Robinson G.), } \\
\text { Hobson (1971) }\end{array}$ \\
\hline *Girella laevifrons & Castro-Romero et al. (2016) \\
\hline Girella nigricans & MacGinitie (1937), Wilson (1935b) \\
\hline *Hemilutjanus \\
macrophthalmus & Castro-Romero et al. (2016) \\
\hline Hypsypops rubicundus & MacGinitie (1937), Wilson (1935) \\
\hline Hypsurus caryi & Hobson (1971), Love and Moser (1983) \\
\hline *Isacia conceptionisn & Castro-Romero et al. (2016) \\
\hline Lampris guttatus & Brian (1898) \\
\hline Lithognathus mormyrus & Zuniga and Suau (1967) \\
\hline Liza richardsonii & Boxshall (1986) \\
\hline Medialuna californiensis & Hobson (1971) \\
\hline$* *$ Micrometrus minimus & Hobson (1971) \\
\hline$*$ Mugil cephalus & Castro-Romero et al. (2016) \\
\hline Mullus barbatus barbatus & Delamare Deboutteville and Nunes Ruivo (1951) \\
\hline Mullus surmuletus & Delamare Deboutteville and Nunes Ruivo (1951), this study \\
\hline$*$ Odonthestes regia & Castro-Romero et al. (2016) \\
\hline$*$ Pagellus bogaraveo & Gooding (1957), Hermida et al. (2013), Hermida et al. (2015) \\
\hline Pagellus erythrinus & $\begin{array}{l}\text { Delamare Deboutteville and Nunes Ruivo (1951), Larraneta } \\
\text { (1964), Boxshall (1986), Gooding (1957) }\end{array}$ \\
\hline Pagrus pagrus & Ramdane and Trilles (2007) \\
\hline
\end{tabular}


Table 1 (continued): Hosts of Peniculus fistula fistula in alphabetical order; * Hosts after those listed by Bunkley-Williams and Williams (2009); ** Hosts for those not listed by Bunkley-Williams and Williams (2009).

\begin{tabular}{|l|l|}
\hline \multicolumn{1}{|c|}{ Hosts } & \multicolumn{1}{c|}{ Authors } \\
\hline **Paralabrax clathratus & (Love and Moser 1983) (personal communication Schultze D.) \\
\hline **Paralabrax nebulifer & (Love and Moser 1983) (personal communication Schultze D.) \\
\hline Phanerodon furcatus & Hobson (1971), Love and Moser (1983) \\
\hline *Prolatilus jugularis & Sep'ulveda et al. (2004), Castro-Romero et al. (2016) \\
\hline Pseudopercis semifasciata & Claus (1868) \\
\hline **Rhacochilus toxotes & Hobson (1971) \\
\hline **Rhacochilus vacca & Hobson (1971) \\
\hline Scorpis lineolata & Boxshall (1986) \\
\hline Synagrops microlepis & Capart (1959) \\
\hline **Trachurus symmetricus & Hobson (1971) \\
\hline Trachurus trachurus & Candeias (1955) \\
\hline Trachurus picturatus & Candeias (1955) \\
\hline Zeus faber & Nordmann (1832), Brian (1906) \\
\hline Xenistius californiensis & Sikkel (1985) \\
\hline
\end{tabular}

In this study, forty nine host species parasitizing Peniculus fistula fistula were listed in table 1. Bunkley-Williams and Williams (2009) presented a host checklist of Peniculus fistula fistula. They determined 40 host species of Peniculus fistula fistula, but it includes some forgetten host and incorrect host.

Williams and Bunkley-Williams (2009) presented Symphodus melanocercus on host list of Peniculus fistula fistula. When investigated this host, one reference is only found. Arnal and Moran (2001) found Peniculus fistula fistula in the gut of host as diet of Symphodus melanocercus. Grutter (2002) listed that several parasitic copepods (caligids, pennellids, bomolochids, pandarids, hastchekia, and lernaeids) were eaten by the cleaner fish. Thus, Symphodus melanocercus is removed from the present table.

Hosts of Peniculus fissipes were added as hosts of Peniculus fistula fistula in this table. Hosts of Peniculus fistula fistula reported by Wilson (1917) and Boxshall (1986) were not added to table because of uncertain of valid species level.

The hosts parasitism with Peniculus fistula fistula was examined according to order characteristics $84 \%$ of 49 host belongs to Perciformes, and 16\% to Zeiformes, Atheriniformes, Beloniformes, Mugiliformes, Lampriformes. The hosts parasitism with Peniculus fistula fistula was examined according to family characteristics $30 \%$ of 49 host belongs to Embiotocidae (eight species) and Sparidae (seven species), and 70\% to Acropomatidae, Atherinidae, Atherinopsidae, Belonidae, Caproidae, Carangidae, Haemulidae, Kyphosidae, Lampridae, Mugilidae, Mullidae, Pinguipedidae, Pomacentridae, Sciaenidae, Serranidae, Sparidae, Coryphaenidae and Zeidae. The hosts parasitism with Peniculus fistula fistula was examined according to habitat selections; $45 \%$ of 49 host fish species are demersal; $21 \%$ of them benthopelagic; $12 \%$ reef-associated; $14 \%$ pelagic-neritic; $4 \%$ bathypelagic, $4 \%$ pelagicoceanic. The hosts parasitism with Peniculus fistula fistula examined according to feeding habits; $63 \%$ of 49 host fish species are carnivorous; 29\% omnivorous, 8\% herbivorous. 
Öktener (2014, 2015) revised two checklists regarding helminth of marine and freshwater fish of Turkey, after 2003 and 2005. For example, after the helminth checklist of marine fish in Turkey was published by Öktener (2005), the number of parasite species increased from 114 to 198, to date (Öktener, 2014). Alaş and Öktener (2015) compared both online database such as WoRMS, Fishbase and checklist studies about fishparasite. The publications concerning fish-parasite checklist studies are important taxonomic documents. These publications aim to determine: a) the biological diversity, b) the host selectivity, c) the geographic distribution of fish zoonoses, d) the fish-parasite relationships, and e) the complexity of fish parasite fauna among different environments (Alaş and Öktener, 2015).

The online databases of both fish and parasite should include data of both civil society organizations and international scientific centres. Online database (ITIS, 2018; Froese and Pauly (eds), 2018; WoRMS Editorial Board, 2018; Pollerspöck and Straube, 2018, etc.) can contribute to keep update biodiversity and taxonomy records, as well as the current status of the existing flora and fauna in relation to their geographical distribution (Alaş and Öktener, 2015).

\section{CONCLUSIONS}

Checklists are important in achieving all of data about parasite and hosts among the countries at a glance. Obviously, the validity of names and synonyms of parasite and host species may change over time. Reports of parasite findings may be published at different/same dates and regions by different researchers (Öktener, 2008; Vidjak et al., 2008). Some information can not be reached (Wilson, 1917, 1935). The revision of checklist studies are important, equally to the possibility of sharing their updates to much more readers. In this sense, checklist studies may include some disadvantages being restrictive and sometimes with some not updated information. Thus, we sustain that online databases are very useful in minimizing doubtful and erroneous reports and notifications of both parasite and host. Therefore, we think online database are more efficient than checklist articles, because they can facilitate in real time the dissemination of information between both the scientific and non-scientific communities.

Öktener (2008) not presented checklist of parasites of Coryphaena hippurus. On the contrary, Bunkley-Williams and Williams (2009) evaluated that Öktener's (2008) article as checklist. But their article also includes some prejudiced comments and missing information about parasite-host. In this publication, we also indicated to emphasize about including actual information and being ease for correction of wrong information in the online databases.

\section{ACKNOWLEDGEMENTS}

The sampled parasites were obtained during TAGEM/HAYSUD/2014/05/01 project, conducted by the Sheep Research Institute of Ministry of Food, Agriculture and Livestock of Türkiye. 


\section{REFERENCES}

1. Alaş A., Öktener A. and Türker Çakır D., 2015 - Review of parasitic copepods recorded in fish from Turkey, Transylvanian Review of Systematical and Ecological Research, 17, 1, 39-62, https://doi.org/10.1515/trser-2015-0047.

2. Alexander P. D., 1983 - Peniculus haemuloni, a new species of copepod (Siphonostomatoida: Pennellidae) parasitic on Haemulon steindachneri from Ubatuba, Brazil, Bulletin of the British Museum (Natural History) (Zoology), 45, 381-385, https://doi.org/10.5962/bhl.part.28007.

3. Arnal C. and Morand S., 2001 - Importance of ectoparasites and mucus in cleaning interactions in Mediterranean cleaner wrasse Symphodus melanocercus, Marine Biology, 138, 4, 777-784.

4. Bănăduc D., Rey S., Trichkova T., Lenhardt M. and Curtean-Bănăduc A., 2016 - The Lower Danube River - Danube Delta - North West Black Sea: A pivotal area of major interest for the past, present and future of its fish fauna - A short review, Science of the Total Environment, 545-546, 137-151, DOI: 10.1016/j.scitotenv.2015.12.058, ISSN 0048-9607, eISSN 1879-1026.

5. Bilecenoğlu M., Kaya M., Cihangir B. and Çiçek E., 2014 - An updated checklist of the marine fishes of Turkey, Turkish Journal of Zoology, 38, 901-929.

6. Boxshall G. A., 1986 - A new genus and two new species of Pennellidae (Copepoda: Siphonostomatoida) and an analysis of evolution within the family, Systematic Parasitology, 8, 215-225, https://doi.org/10.1007/BF00009890.

7. Brian A., 1898 - I. Catalogo di Copepodi parassiti dei pesci della Liguria, Atti della Société Ligustica di Scienze Naturali e Geografiche, 9, 5-31. (in Italian)

8. Brian A., 1906 - Copepodi parassiti dei pesci d'ltalia, Genova, 190, https://doi.org/10.5962/bhl.title.58642. (in Italian)

9. Brian A., 1917 - Note sur Copepodes parasites provenant des Musee Oceanographique de Monaco, Bulletin du Musée océanographique de Monaco, 324-326, 1-8. (in French)

10. Bunkley-Williams L., Williams E. H. and Bashirullah A. K. M., 1998 - Some isopods assoaciated with Venezuelan fishes, Caribbean Marine Studies, 6, 27-30.

11. Bunkley-Williams L. and Williams E. H., 2000 - First Caribbean report of Glossobius impressus (Isopoda: Cymothoidae) and a new host, Fourwing Flyingfish, Hirundichthys affinis, Caribbean Journal of Science, 36, 1-2, 155.

12. Bunkley-Williams L. and Williams E. H., 2009 - Hosts and distribution of Peniculus fistula von Nordman, 1832, Reviews in Fisheries Science, 17, 4, 538-540, http://dx.doi.org/10.1080/10641260903216012.

13. Candeias A., 1955 - Peniculus fistula Nordman, On two new hosts Trachurus trachurus and Trachurus picturatus, Notas e Estudos do Instituto de Biologia Marítima, Lisboa, 8, 1-16.

14. Capart A., 1959 - Copepodes parasites: resultats scientifiques de l'expedition oceanographique Belge dans les eaux cotieres africaines de l'Atlantique Sud (1948-1949), Bulletin de l'Institut Royal des Sciences Naturelles de Belgique, 3, 55-126. (in French)

15. Castro-Romero R., Montes M. M., Martorelli S. R., Sepulveda D., Tapia S. and MartinezAquino A., 2016 - Integrative taxonomy of Peniculus, Metapeniculus, and Trifur (Siphonostomatoida: Pennellidae), copepod parasites of marine fishes from Chile: species delimitation analyses using DNA barcoding and morphological evidence, Systematics and Biodiversity, 14, 5, 466-483, https://doi.org/10.1080/14772000.2016.1158213.

16. Claus C., 1868 - Beobachtungen über Lernaeocera, Peniculus and Lernaea, bin Beitrag zur Naturgeschichte der Lernaeen, Schriften der Gesellschaft zur Beförderung der gesammten Naturwissenschaften zu Marburg, Marburg und Leipzig, 1868, II, 32. (in German)

17. Delamare Deboutteville C. and Nunes-Ruivo L., 1951 - Existence de "formes biologiques" chez Peniculus fistula (Rudolphi) (Copepoda), Vie et Milieu, 2, 448-458. (in French) 
18. Dyer W. G., Bunkley-Williams L. and Williams E. H., 1997 - Parasites of the Dolphin fish (Coryphaena hippurus) in Puerto Rico, Journal of Helminthological Society of Washington, 64, 188-194.

19. Froese R. and Pauly D. (eds), 2018 - FishBase, World Wide Web electronic publication, www.fishbase.org, version (06/2018).

20. Gooding R. U., 1957 - On some copepoda from Plymouth, mainly associated with invertebrates, including three new species, Journal of the Marine Biological Association of the United Kingdom, 36, 195-221, https://doi.org/10.1017/S0025315400016714.

21. Grutter A. S., 2002 - Cleaning symbioses from the parasites' perspective, Parasitology, 124, 65-81, https://doi.org/10.1017/S0031182002001488.

22. Hermida M., Cruz C. and Saraiva A., 2013a - Parasites as biological tags for stock identification of blackspot seabream, Pagellus bogaraveo, in Portuguese northeast Atlantic waters, Scientia Marina, 77, 4, 607-615, Doi: 10.3989/scimar.03859.17A.

23. Hermida M., Cruz C. and Saraiva A., 2013b - Ectoparasites of the blackspot seabream Pagellus bogaraveo (Teleostei: Sparidae) from Portuguese waters of the north-east Atlantic, Journal of the Marine Biological Association of the United Kingdom, 93, 2, 503-510, https://doi.org/10.1017/S0025315412000057.

24. Hobson E. S., 1971 - Cleaning symbiosis among California inshore fishes, United States National Marine Fish Service Fish Bulletin, 69, 491-523.

25. ITIS, 2018 - Integrated Taxonomic Information System (ITIS), http://www.itis.gov, accessed 2018-11-11.

26. Kabata Z. and Wilkes S. N., 1977 - Peniculus asinus (Copepoda: Pennellidae), a new species of copepod parasitic on fishes of the genus Sebastes along the west coast of North America, Canadian Journal of Zoology, 55, 1988-1991, https://doi.org/10.1139/z77-257.

27. K1lıc H. 1999 - Site selection. The case of Turkey. Aquaculture planning in Mediterranean countries, CIHEAM - Cahiers Options Méditerranéennes, 43, 25-33.

28. Kritsky D. C. and Öktener A., 2015 - Solostamenides paucitesticulatus n. sp. (Monogenoidea: Mazocraeidea: Microcotylidae) from the freshwater mullet Liza abu (Heckel) (Mugiliformes: Mugilidae) from Atatürk Reservoir on the Euphrates River in southern Turkey, Systematic Parasitology, 91, 139-144, https://doi.org/10.1007/s11230-015-9562-3.

29. Larraneta M. G., 1964 - Sobre la biologia de Pagellus erythrinus (L.) especialmente del de las costas de Castellon, Investigacion Pesquera, 27, 121-146. (in Spanish)

30. Love M. L. and Moser M., 1983 - A checklist of parasites of California, Oregon, and Washington marine and estuarine fishes, NOAA Technical Report NMFS SSRF-777, 572.

31. Luna S. M., 2009 - Diseases, in dolphin and Pompano dolphin, in FishBase (Froese R. and Pauly D., eds), World Wide Web electronic publication, www.fishbase.org, version (01/2009) (1990, 1994, 2006), (cited by Williams and Bunkley-Williams 2010).

32. MacGinitie G. E., 1937 - Notes on the natural history of several marine crustacea, The American Midland Naturalist, 18, 6, 1031-1037, Doi: 10.2307/2420601.

33. Moon M. S. and Choi S. H., 2014 - Description of two species of Peniculus von Nordmann, 1832 (Copepoda: Siphonostomatoida: Pennellidae) parasitic on commercial fishes from Korea, including a new species, Systematic Parasitology, 88, 185-193, http://dx.doi.org/10.1007/s11230-014-9493-4.

34. Nordmann A., 1832 - Mikrographische Beitriige zur Naturgeschichte der wirbellosen Thiere, Berlin: Reumer G., 150. (in German)

35. Öktener A. and Sezgin M., 2000 - Mothocya epimerica Costa, 1851 (Flabellifera: Cymothoidae), an Isopod Parasite in the Branchial Cavities of the Black Sea Silverfish Atherina boyeri Risso, 1810 (Perciformes, Atherinidae), Turkish Journal of Marine Science, 6, 1, $23-29$.

36. Öktener A., 2003 - A checklist of metazoan parasites recorded in freshwater fish from Turkey, Zootaxa, 394, 1-28, http://dx.doi.org/10.11646/zootaxa.394.1.1. 
37. Öktener A., 2005 - A checklist of parasitic helminths reported from sixty-five species of marine fish from Turkey including two new records of monogeneans, Zootaxa, 1063, 33-52, http://dx.doi.org/10.11646/zootaxa.1063.1.2.

38. Öktener A., 2008 - Peniculus fistula von Nordmann, 1832 (Copepoda: Pennelidae) parasitic on Coryphaena hippurus Linnaeus, 1758 (Teleostei: Coryphaenidae), Reviews in Fisheries Science, 16, 445-448, http://dx.doi.org/10.1080/10641260802046668.

39. Öktener A., 2014 - Revision of parasitic helminths reported in freshwater fish from Turkey with new records, Transylvanian Review of Systematical and Ecological Research, 16, 1, 1-56, https://doi.org/10.1515/trser-2015-0001.

40. Öktener A., Alaş A. and Türker Çakır D., 2015 - First record of Bomolochus bellones Burmeister, 1833 (Copepoda: Bomolochidae) from Turkish habitats, Vie et Milieu, 65, 3, 1-4.

41. Öktener A., 2015 - An updated checklist of parasitic helminths of marine fish from Turkey, Transylvanian Review of Systematical and Ecological Research, 16, 2, 55-96, https://doi.org/10.1515/trser-2015-0017.

42. Öktener A., Trilles J. P. and Alaş A., 2018 - Elthusa poutassouiensis (Penso, 1939), comb. nov. (Isopoda, Cymothoidae) for Meinertia (Ceratothoa) poutassouiensis, parasite of the blue whiting, Micromesistius poutassou, Bulletin - European Association of Fish Pathologists, 38, 1, 9-20.

43. Olmo A. P., Fernandez M., Raga J. A., Kostadinova A. and Poulin R., 2008 - Halfway up the trophic chain: development of parasite communities in the sparid fish Boops boops, Parasitology, 135, 257-268, https://doi.org/10.1017/S0031182007003691.

44. Palko B. J., Beardsley G. L. and Richards W. J., 1982 - Synopsis of the biological data on dolphin-fishes, Coryphaena hippurus Linnaeus and Coryphaena equiselis Linnaeus, NOAA Report, NMFS Circ. 443, FAO Fish, 130 (cited by Williams and Bunkley-Williams 2010).

45. Pollerspöck J. and Straube N., 2018 - Bibliography Database of living/fossil sharks, rays and chimaeras (Chondrichthyes: Elasmobranchii, Holocephali, www.shark-references.com, World Wide Web electronic publication, Version 2018), accessed in 2018-11-11.

46. Raibaut A., Combes C. and Benoit F., 1998 - Analysis of the parasitic copepod species richness among Mediterranean fish, Journal of Marine Systems, 15, 185-206, https://doi.org/10.1016/S0924-7963(97)00079-1.

47. Ramdane Z. and Trilles J. P. 2007 - Parasitic copepods (Crustacea: Copepoda) from Algerian marine fishes, Zootaxa, 1574, 49-68.

48. Sep'ulveda F., Marin S. L. and Carvajal J., 2004 - Metazoan parasites in wild fish and farmed salmon from aquaculture sites in southern Chile, Aquaculture, 235, 89-100, https://doi.org/10.1016/j.aquaculture.2003.09.015.

49. Sikkel P. C., 1985 - Intraspecific cleaning by juvenile salema, Xenestius californiensis (Pisces: Haemulidae), California Fish Game, 72, 170-172.

50. Venmathi Maran B. A., Moon S. Y., Oh S.-Y., Soh H. Y. and Myoung J. G., 2012 Redescription of two Pennellids (Copepoda, Siphonostomatoida) from Korea with a key to species of Peniculus von Nordmann, 1832, ZooKeys, 243, 1-14.

51. Vidjak O., Zorica B. and Sinov'cic G., 2008 - First record of parasitic copepod Peniculus fistula von Nordmann, 1832 (Sphinostomatoida: Pennelidae) from garfish Belone belone (Linnaeus, 1761) in the Adriatic Sea, Cahiers de Biologie Marine, 49, 209-213.

52. Walter T. C. and Boxshall G., 2018 - World of Copepods database, Peniculus fistula fistula Nordmann, 1832, accessed through: World Register of Marine Species at: http://www.marinespecies.org/aphia.php?p=taxdetails\&id=745880 on 2018-11-29.

53. Williams E. H. and Bunkley-Williams L., 2009 - A 226-year-old dolphin isopod mystery solved: identification of barbugede Pampelfisk, Coryphaena apus Brunnich, 1783, Reviews in Fisheries Science, 17, 557-561, http://dx.doi.org/10.1080/10641260903243495. 
54. Williams E. H. and Bunkley-Williams L., 2010 - Checklists of the parasites of dolphin, Coryphaena hippurus, and Pompano dolphin, equiselis with new records, corrections, and comments on the literature, Reviews in Fisheries Science, 18, 1, 73-93, http://dx.doi.org/10.1080/10641260903295909.

55. Wilson C. B., 1917 - North American parasitic copepods belonging to the family Lernaeidae with a revision of the entire family, Proceedings of the United States National Museum, 53, 1-150, https://doi.org/10.5479/si.00963801.53-2194.1.

56. Wilson C. B., 1935 - Parasitic copepods from the Pacific coast, The American Midland Naturalist, 16, 776-797, https://doi.org/10.5479/si.00963801.35-1652.431.

57. WoRMS Editorial Board, 2018 - World Register of Marine Species, available from http://www.marinespecies.org at VLIZ, accessed 2018-11-29, doi:10.14284/170.

58. Zuniga L. R. and Suau P., 1967 - Nota sombre la presencia de los copepods parasitos Peniculus fistula y Lerneolophus sultanus sobre dos nuevos huespedes, Lithognathus mormyrus y Boops boops, Investigacion Pesquera, 3, 3, 485-487. (in Spanish) 